\title{
MSMB Gene
}

National Cancer Institute

\section{Source}

National Cancer Institute. MSMB Gene. NCI Thesaurus. Code C20804.

This gene may play a role in the modulation of autocrine paracrine factor in reproductive tissues, however a specific function has not been elucidated. 